\title{
Studying Infertility in the Medieval Islamic World: Why and How
}

This study began with an assumption and a question. Assuming that producing children was the primary source of women's value and women's power in medieval Islamic societies, what happened when women failed to produce children? There were good reasons to make this first assumption. After all, anthropological and sociological accounts from many modern Middle Eastern communities describe the importance of motherhood for women and the anxiety surrounding infertility; and members of these modern communities often ascribe such values and anxieties to religion and to centuries-old tradition. Moreover, throughout the contemporary world, arguments in favor of "traditional" or "patriarchal" practices, as well as those rejecting them, have hinged upon the notion that the limitations placed on women exist to either confine them or support them in their role as producers and nurturers of children. ${ }^{1}$ Surely this was also true of the experiences of women in medieval Islamic societies? It raises the question of how those women who could not fulfill that role were treated.

From the start, it has also been clear that this line of reasoning is problematic. There are the definitional problems, such as what do we mean by "power," when should communal practices be labeled "Islamic," and what is the significance of the plural in the phrase "Islamic societies"? These concerns are real, but they represent a detour from the discussion at hand, not an actual contradiction or problematization of the supposition that motherhood was the primary role assigned to women, around which the traditional system, particularly as enshrined in Islamic law, was organized. Here, however, even a cursory knowledge of Islamic family law suggests a possibly fatal flaw with this argument: Islamic law barely mentions infertility and in no way overtly penalizes barren women. ${ }^{2}$ Indeed, it makes rather little mention of maternity itself. ${ }^{3}$ How then could it play

1 For some examples of the ambiguities of measures which serve to support and constrict women in their roles as producers of children, see Remke Kruk, "Pregnancy and Its Social Consequences In Mediaeval And Traditional Arab Society” Quaderni Di Studi Arabi 5/6 (1987):418-30.

2 The case of slave women represents something of an exception to this rule, as such women stood to gain some legal protections if they bore their masters' children. See Y. Mirza, "Remembering the Umm al-Walad," in Concubines and Courtesans: Women and Slavery in Islamic History, ed. M. Gordon and K.A. Hain (Oxford: Oxford University Press, 2017), 297-337.

3 The most recent scholarship on motherhood in the medieval Islamic world, Kathryn Kueny's Conceiving Identities: Maternity in Medieval Muslim Discourse and Practice (Albany: State University of New York Press, 2013), does not include any extended discussion of Islamic law.

Ә OpenAccess. (C) 2020 Sara Verskin, published by De Gruyter. (cc))BY-NC-ND This work is licensed under the Creative Commons Attribution-NonCommercial-NoDerivatives 4.0 License.

https://doi.org/10.1515/9783110596588-002 
a role in shaping the experiences of infertile women? Ultimately, it is the answer to this question which constitutes the subject of this book.

\section{Why study the experiences of barren women?}

For students of medieval Islamic societies, the study of barren women offers two benefits. First, it illuminates a phenomenon that is important in and of itself, as it was experienced by women in all eras and places, and with life-changing consequences. Secondly, in exploring the factors that shape the peculiar experience of infertility, we shed light on broader issues in Middle Eastern and Islamic history. In studying reproduction, we gain insight into the interplay between the medical and religious explanations of biological events and the significance attributed to them. In studying medical interventions, we gain insight into the remarkably diverse marketplace of ideas about health that existed in some medieval communities, and the anxieties some people felt as a result of the multiplicity of authorities and forms of knowledge. We see competition and anxiety expressed by religious authorities against medical authorities and practitioners of healing magic, male medical practitioners against female ones, and male religious culture against female religious culture. In studying women's sources of healthcare, we gain new insights into the meaning behind regulations governing women's modesty and social interactions. Finally, in studying the options available to childless women throughout their life cycles, we can fine-tune our understanding of some aspects of the institutions of Islamic marriage, divorce, and polygamy in ways that make us re-examine, and at times contradict, certain assumptions about patriarchy, paternity, motherhood, and women's vulnerability and empowerment within the Islamic legal system.

The picture of patriarchy that emerges from this study of infertility is a complex and somewhat surprising one. While much ink has been spilled by others in describing patriarchal attempts to exert male control over women's sexual organs so as to ensure fathers' confidence in their own paternity, this study shows the extent to which men depended upon and trusted women to individually monitor and interpret their own reproductive statuses. It also shows both the legal and medical willingness to tolerate, and even embrace, reproductive uncertainty and ambiguity. However, it also suggests that the social constraints urged upon women were understood by many jurists as existing for reasons beyond the need to guard against sexual and reproductive violations. Rather they were also put in place to guard against the threat of religious and intellectual syncretism, a threat to which some jurists thought women were particularly at risk, and partic- 
ularly so during their experiences of events connected with health, birth, and death.

\section{The importance of infertility as a phenomenon}

Writing in Tunis in the 1970s, the sociologist Abdelwahab Bouhdiba produced a lengthy, dramatic, and damning depiction of the importance of fertility and the prospect of sterility for women in what he termed contemporary "Arabo-Muslim" society. ${ }^{4}$ His La Sexualité en Islam highlights the role played by Islamic legal norms in making the fate of women contingent upon their reproductive success. Because of the weakness of a woman's position as a wife, a woman must seek safety through the institution of motherhood, he claims. Polygamy, divorce, and inheritance law all conspire to pressure women into producing children, as a means of obtaining loyalty, respect, care, and financial security in a system which is otherwise lacking in those things. ${ }^{5}$ He concludes:

Having children in the traditional Arabo-Muslim society is the fundamental element of security for a woman. Woe betide the sterile woman ... Motherhood, then, was a protection. It was the only security for a woman - there was practically no other . . . So, given the "system" and the structures of the environment, the Arab woman tries to increase her chances by having as many pregnancies as possible. Hence that obsession with children - have children, more children and still more children!

Bouhdiba argues that even in The Thousand and One Nights, the classic story of the triumph of feminine brains over masculine brawn, what enables Shahrezad to survive is not her storytelling abilities, but rather her providing the king with three sons in the space of thirty-three months. "One of them walked, one of them crawled, and one was at the breast." 6

Other sociologists and ethnographers describing their findings in twentiethcentury Iran, Turkey, ${ }^{7}$ Palestine,${ }^{8}$ Jordan, ${ }^{9}$ Egypt, ${ }^{10}$ and Morocco ${ }^{11}$ have empha-

4 A. Bouhdiba, Sexuality in Islam (London: Saqi Books, 2004), 215f. La Sexualité en Islam (Paris: Presses Universitaires de France, 1975), $263 \mathrm{f}$.

5 For an overview of Islamic texts that refer to the honor due to mothers, see A. Giladi, Muslim Midwives: The Craft of Birthing in the Premodern Middle East (New York: Cambridge University Press, 2015), 37-56.

6 Bouhdiba, Sexuality in Islam, 216.

7 C. Delaney, The Seed and the Soil: Gender and Cosmology in Turkish Village Society (Berkeley: University of California Press, 1991), 59. Of all the accounts of women's experiences in the Middle East that I have come across, Delaney's places the least emphasis on the stresses caused by in- 
sized the role familial honor and social pressure play in shaping the experience of childless women, in addition to the fear of divorce. The French sociologist Paul Vieille, based on interviews with urban and rural women living in Iran in the 1960s, vividly depicts the shame associated with infertility and the pressure brought to bear in compelling young women to take measures to demonstrate their own fertility.

\begin{abstract}
After marriage all those who surround a young wife await with anxiety the announcement of a pregnancy. The event releases an anxiety; thenceforth the young wife will be cherished by her husband and her in-laws. If, on the contrary, there is a delay, anxiety grows on all sides. The father of the young girl has given a product for reproduction; he is discredited by his daughter who does not immediately promise a child. The husband's family, on its side, has acquired a young wife to increase its descendants; if her sterility continues, the husband loses interest in his wife and threatens to send her back or to take a second wife. The household is constituted to procreate; sterility is a broken contract. The young wife who is, habitually and without proof, taken to be responsible for the sterility of the couple, will do everything to change her state: pilgrimages, magic practices, potions, and so forth. If she does not succeed, she will have only a diminished status, and her family will feel dishonored by it.

Social incitements to childbirth continue after the first birth. There are, notably, the uncertainties of the position of the wife in the household; the marriage is easily broken by the will of the husband alone. Even if this does not happen in the countryside, ${ }^{12}$ the op-
\end{abstract}

fertility and the anxiety to have children. Writing about her fieldwork in a Turkish village in the early 1980s, she also mentions that abortion is common, and quite dangerous for the mother. However, she does note that, "If a child is not produced within a reasonable amount of time, the man is free to divorce or take a second wife. Although polygyny is forbidden in modern Turkish law, it sometimes occurs in villages where traditions of the Seriat (Islamic law) still operate. The system of beliefs implies that the marriage bond is less important than physiological paternity.” Ibid., 53.

8 H. Granqvist, Marriage Conditions in a Palestinian Village, 1:117; 2:116, 244-6, and idem, Child Problems Among the Arabs (Södorström, 1950), 76-7, 224. T. Canaan, "Unwritten Laws Affecting the Arab Woman of Palestine," Journal of the Palestine Oriental Society 11 (1931), 175.

9 R. Antoun, "Social Organization and the Life Cycle in an Arab Village," Ethnology 6.3 (1967), $302-3$.

10 Ḥ. 'Ammār, Growing up in an Egyptian village; Silwa, Province of Aswan (New York, Octagon Books, 1966), 94. S. Morsey, Gender, Sickness, and Healing in Rural Egypt (Boulder, CO: Westview Press, 1993), 48, 54, 75. and "Sex Differences and Folk Illness," in Women in the Muslim World, L. Beck and N. Keddie (Cambridge, Mass.: Harvard University Press, 1978), 604-605. M. Inhorn, Infertility and patriarchy: the cultural politics of gender and family life in Egypt (Philadelphia: University of Pennsylvania Press, 1996).

11 V. Maher, "Women and Social Change in Morocco," in Women in the Muslim World, ed. Lois Beck and Nikki Keddie (Cambridge, Mass: Harvard University Press, 1978), 104.

12 Erika Friedl's account of a remote Iranian mountain village in the 1970s and early 1980s confirms this: “There aren't many childless couples in Deh Koh, and of the few not one ever split up, 
tion left to the husband to send back his wife easily leads the latter to look for means to attach her to her home. Children are reputed to be "nails" that attach the wife to the home. After marriage, women hasten to multiply these ties which guarantee them against repudiation.

... the group of women: they actively surround the young wife, initiate her, guide her through the first pregnancies, welcome the newborn, and combat sterility. In them are transmitted ancient popular practices regarding magic, pharmacy, and medicine. They help the young wives and exert a considerable pressure in favor of fecundity. ${ }^{13}$

The effects of such pressure lead women to engage in a "quest for conception," memorably depicted by Erika Friedl in Women of Deh Koh, which includes a chapter portraying the experience of a childless young wife seeking aid in the wake of the Iranian Revolution, ${ }^{14}$ and by Marcia Inhorn, in her books The Quest for Conception: Gender, Infertility, and Egyptian Medical Traditions and Infertility and Patriarchy: The Cultural Politics of Gender and Family Life in Egypt. In the course of such quests, infertile women seek assistance from ethnomedical practitioners, religious saints, and practitioners of biomedicine. A study from modern Egypt shows that concerns about infertility, and the perception that pregnancy is not occurring quickly enough, account for more than half of all women's medical visits, whether to biomedical physicians or practitioners of indigenous medicine. ${ }^{15}$

As depicted in modern accounts, in the course of this "quest for conception," women encounter and navigate Islamic legal culture in complex ways. The delivery of medical attention and care to women is potentially fraught as a result of modesty concerns. Moreover, medical systems and treatments, such as biomedical healing, humoral healing, magical healing, prayer, and pilgrimage rituals to attain saintly blessing, baraka, are subject to religious categorizations on the basis of theological orthodoxy and heresy. Whether a form of medical intervention meets with approval or disapproval from religious authorities is not dependent on whether such interventions are "traditional," validated by either

and no husband ever took a second wife because of his first wife's barrenness. Indeed after the first few rough years of crushed expectations, attempted cures, amulets and accusations, pilgrimages, travels to doctors, fights, sneers, and humiliating pity, and after hope has dimmed to a faint flicker deep in the couple's hearts, they tune in to each other as companions in misery and live more peacefully and leisurely than most of their neighbors harassed by large families." E. Friedl, Women of Deh Koh (London: Penguin Books, 1991), 48.

13 P. Vieille, "Family Alliance and Sexual Politics," in Women in the Muslim World, ed. Lois Beck and Nikki Keddie (Cambridge, Mass: Harvard University Press, 1978), 457.

14 Friedl, Women of Deh Koh, 47-65.

15 H. Khattab, N. Younis, and H. Zurayk, Women, Reproduction, and Health in Rural Egypt (Cairo: American University in Cairo Press, 1999), 65. 
historical precedent or indigeneity. Indeed, among some devout Muslims, centuries-old medical systems are viewed with more suspicion than the more recent biomedicine. As Inhorn writes with respect to Egypt:

Interestingly, contemporary Islamists tend to condone most biomedical therapies as the creation of God - as being "God's medicine." Yet, it is truly ironic that only modern, Westernbased biomedicine is deemed religiously acceptable, given the rich history of Yūnāni-inspired Islamic and prophetic medicine in Egypt. As we shall see, many of the contemporary ethnomedical practices found in Egypt derive from these early, religiously acceptable medical traditions, which are now viewed as unorthodox by Islamist elements in Egyptian society. ${ }^{16}$

All of these characterizations of modern Muslim women's experiences highlight the importance of the Islamic legal tradition for understanding contemporary familial relations, gender roles, and attitudes toward medical treatment. ${ }^{17}$ And yet, due to the paucity of scholarship, ${ }^{18}$ anthropologists have largely skipped over the medieval Islamic period when describing the significance and consequences of infertility, reaching instead for literature from the Greco-Roman or even Biblical periods. ${ }^{19}$

Where scholarship about the intersection of Islamic law, science, and gender exists, it has been very useful. Thus Basim Musallam's work on the approaches of medieval Islamic physicians towards the "one-seed" and "two-seed theories" of conception, and the intertwined relationship between Islamic holy texts and those medical theories, has become the go-to text, almost the only one, for those wishing to provide some medieval Islamic context for contemporary conversations about the intersection of gender, medicine, and Islamic legal orthodoxy. ${ }^{20}$ Still lacking, however, are studies of medieval interactions between male physicians and female patients, medieval attitudes toward the "quest for conception"

16 M. Inhorn, Quest for Conception: Gender, Infertility, and Egyptian Medical Traditions (Philadelphia: University of Pennsylvania Press, 1994), 94.

17 Inhorn, Infertility and Patriarchy, 26.

18 In an unusual dissertation, Egyptologist Nicole Hansen attempted to study 5000 years worth of fertility rituals in Egypt, from the Old Kingdom to the present. The pre-colonial Islamic era is the most sparsely sourced period. N. Hansen, "Motherhood in the Mother of the World: continuity and change of reproductive concepts and practices in Egypt from ancient to modern times" (PhD diss., University of Chicago, 2006).

19 E.g., Taufik Canaan, "Unwritten Laws Affecting the Arab Woman of Palestine," 175, 203. R. Patai, Sex and Family in the Bible and the Middle East (New York: Doubleday, 1959), 76-84. 20 B. Musallam, "The Human Embryo in Arabic Scientific and Religious Thought," in The Human Embryo: Aristotle and the Arabic and European Traditions. ed. G. R. Dunstan (Exeter: University of Exeter Press, 1990), 32-46. 
and orthodox and heretical forms of medical treatment, and the extent to which modern women's experiences of disempowerment or fear of disempowerment as a result of infertility were shared by their medieval counterparts. This study represents a first foray, among what I hope will be many future ones, into filling those gaps in our knowledge.

\section{Studying infertility to shed light on related issues in Middle Eastern and Islamic history}

The exploration of infertility has much to offer students of medieval Islamic communities generally, well beyond specific information about barren women. Infertility represents an extreme case in which a woman's multiple roles as a mother, as a possessor and object of sexual desire, and as a conduit that binds families together (genealogically and financially) through marriage, are in direct conflict with each other. By examining this extreme case, we can gain insights into the relative significance of, and tensions between, those roles.

As other scholars have demonstrated, analyzing the ramifications of a marginal biological phenomenon and the rather specialized legal discourse surrounding it can yield fruitful and clarifying insights about more common experiences and pervasive social structures. For example, Paula Sanders's study of the treatment of hermaphrodites in medieval Islamic law not only provides information about what hermaphrodites might have experienced, but also illuminates the process, purpose, and scope of gender differentiation in Islamic law more generally. ${ }^{21}$ The above-mentioned article by Basim Musallam, on medieval embryology, not only explains specific claims about genetics, but also makes a broader point, showing just how important scientific beliefs were in framing large branches of Islamic law, as it pertains to sexuality, contraception, and abortion. ${ }^{22}$ Moreover, he shows that existing Islamic texts and laws favored and promoted certain scientific theories over others. My own study of infertility sheds light on a host of issues surrounding the physiology of pubescence, menstruation, and amenorrhea and their importance for understanding Islamic marriage and divorce law.

Exploring infertility also draws our attention to medieval medical treatment, both generally and with regard to women specifically. Because infertility was a

21 P. Sanders, "Gendering the Ungendered Body: Hermaphrodites in Medieval Islamic Law," in Women in Middle Eastern History: Shifting Boundaries in Sex and Gender, ed. Nikki R. Keddie and Beth Baron (New Haven: Yale University Press, 1991), 74-95.

22 Musallam, "The Human Embryo in Arabic Scientific and Religious Thought," 37-8, 42-3. 
long-term problem, rather than an emergency, and because it was perceived as an affliction which could be attributed to multiple sources, in theory a medieval childless woman would have had ample time to seek an array of treatment options, just as modern childless women do today. And, just as they do today, the practitioners offering treatment existed in an environment in which they competed for the exclusive trust of their patients, while their patients often availed themselves of a hybrid system for understanding what, precisely, was wrong with their bodies. An analysis of infertile women's treatment options therefore leads us to examine who was offering explanations and treatments for ill health, the relationship between patients and those offering them treatment, and the relationship between competing practitioners. The information about competing practitioners further leads us to consider the question of the extent to which male authorities expected their views and writings about women's bodies to reach and influence women themselves.

Finally, studying infertility provides us with an opportunity to re-examine aspects of Islamic law which are regularly mentioned in medieval texts, but which have been ignored or at times misinterpreted in modern scholarship. For example, a great deal of attention has been paid to juristic concerns about interaction between women and unrelated men. However, little attention has been paid to the frequently expressed medieval concerns about women interacting with their fellow women. Similarly understudied are the frequent mentions of the legal outcomes of biologically unexpected circumstances - wives who are not old and yet do not menstruate regularly, husbands and wives who are in some way impotent and unable to engage in normal sexual activity, and women who claim to be pregnant with a fetus for years on end. Studying infertility brings to the fore and helps to contextualize the significance of these legal discussions.

\section{Methodological considerations and the nature of the sources}

\section{Previous studies as methodological models}

At the end of his life, the historian of medicine Michael Dols, produced a magnum opus, Majnūn: The Madman in Medieval Islamic Society with the objective of placing "the subject of insanity in its historical context, to examine its significance, not only within the fields of medicine, theology, magic, and law, but also 
within the social milieu of Islamic society." 23 In his book, Dols traces the history of medical thinking about the causes and treatments of mental illness in the Greek medical tradition and the Arabic one, as well as in Jewish, Christian, and Islamic texts. He goes on to describe the institutions built to provide care for the mentally ill. He then addresses moral perceptions of the significance of madness, as depicted by poets, mystics, and belle-lettrists. Finally, he explores the legal significance and consequences of insanity. In its ideal form, a study of medieval infertility would be structured using a similar template. My own study is far more limited than Dols's book, focusing specifically on the medical and legal discussions of the condition at hand. It is, however, written with Dols's scope in mind, both in terms of the larger questions it seeks to illuminate, and in terms of its handling of recondite source materials.

The similarities between infertility and madness are striking. The causes of both were simultaneously attributed to both "natural" biological dysfunction and divine intervention, and the onset of the disease was difficult to pinpoint. Both posed long-term problems, and therefore there was opportunity in the course of a single patient's lifetime to attempt multiple forms of treatment. Both affected not just the ill person themselves, but the families and communities that surrounded them. And for both, the historian lacks first-person narratives of the experiences of the unfortunate patients.

In his introduction, Dols describes the ways in which the nature of the sources available shaped his project, its methodology, and its limitations; much of what he writes is also transferable to the study of infertility. He notes that the paucity of descriptive resources necessitates pulling together sources that come from a wide range of locations and times. This means that "the fragmentary nature of the source material makes it quite difficult to delineate the subtle changes in the beliefs and practices concerning insanity or, conversely to avoid a static view of the subject." ${ }^{24}$ Moreover, in both the medical and legal literature, the depictions of mental disturbances are "prescriptive rather than descriptive," 25 meaning that the depictions of the phenomenon in these texts are there to provide a rationale for a particular method of treatment, rather than a clinical description, and therefore mapping contemporary diagnoses onto medieval medical descriptions requires making some interpretive assumptions. ${ }^{26}$ The

23 M. Dols, Majnūn: The Madman in Medieval Islamic Society (Oxford: Clarendon Press, 1992), vii.

24 Dols, Majnūn, 2.

25 Ibid., 1.

26 Among Dols's assumptions are: (a) That mental illnesses found in medieval Islamic societies are similar to the ones recognized by modern medicine. (b) That based on biology, geography, 
medical data also does not lend itself to quantification at all. Most importantly, "nor are there, to my knowledge, any reliable personal records of the insane that would allow them to speak for themselves; the rarity of authentic voices robs this work of immediacy, comfortably distancing us from what was often, surely, a painful reality." ${ }^{27}$

All of these methodological complications also pertain to the study of the treatment of barren women in the medieval Middle East. For Dols, these complications do not preclude scholarly analysis. He writes, "What can be expected, however, is a relatively firm grasp of the interpretations of irrationality, and a tessellated picture of the madman in medieval society." ${ }^{28}$ This is also my task - to explore how infertility was understood and learn about the experiences of and attitudes towards infertile women from as many perspectives as are available to us.

Discussions of infertility include several unique components, not present in discussions of madness. Infertility is one place where social and religious expectations of gendered roles, scientific disputes about conception and reproduction, and familial dynamics, all intersect. For this reason, I have also looked to Basim Musallam's Sex and Society in Islam: Birth Control Before the Nineteenth Century as a model for my own work. There Musallam uses the specific issue of contraception as an entry point into a broader analysis of Islamic attitudes generally toward sexual activity and marriage. In doing so, he demonstrates

trade, and war, we can assume that mental illness caused by tropical diseases, malnutrition, and narcotics caused mental illness to be widespread and to probably increase over time. (c) That certain sociological factors pertaining to the segregation of minorities and women "may have produced a greater incidence of psychoneuroses and personality disorders than would be found in modern Western society" (p.3n5). My assumptions for my own work are similar to (a) and (b), but have nothing comparable to (c). Medieval infertility was due to the same sorts of causes as modern infertility, though most likely the prevalence of each particular cause was different (e.g. infertility or diminished fertility due to malnutrition or anemia would have been more prevalent in the past when more communities experienced periods of famine). In our own era, a common cause of infertility is sexually transmitted infections. Some of these infections are known to have existed in the past. For example the bacillus which causes gonorrhea, which was rampant in the pre-modern world, in particular is known to cause female infertility, even in women who have had only limited exposure to the infection and who are otherwise asymptomatic. At the moment, there is insufficient scholarship to make an argument as to whether such infections were more or less prevalent in various medieval populations in the Middle East. For an example of what such scholarship might look like, consider a study with respect to Japan. W. Johnston, "Sexually Transmitted Diseases and Demographic Change in Early Modern Japan.” East Asian Science, Technology, and Medicine 30 (2009):74-92. 27 Dols, Majnūn, 2

28 Dols, Majnūn, 2. 
how very large a role negative and positive evaluations of sexuality played in defining the institution of marriage, in both the Christian and Islamic worlds, even though this might not be intuitive given that both Christianity and Islam ultimately permit sexual activity within the confines of marriage. Additionally, he shows how Islamic law responded to competing medical theories of conception and to the biological reality that contraceptives were known to not always be reliable. His book also offers insights into how having children or avoiding childbirth were alternately understood as potentially both desirable and undesirable from the point of view of women's well-being. All of this stems from the discussion of contraception, which is to say, the voluntary decoupling of sexual relations from reproduction. My contribution to these topics stems from the study of the involuntary decoupling of sexual relations from reproduction.

\section{The nature of the primary texts, and the promises, limitations, and pitfalls of studying intellectual history using sources spanning vast periods and topographies}

The scope, methodology, and precision of this study have been influenced by the sources currently available. None of the medieval sources upon which I draw were produced by Muslim women. As Kathryn Kueny noted in her study of maternity, "it is impossible to assume that [women's] voices and contributions to Muslim discourse and practice, if any, may be fully uncovered." ${ }^{29}$ In recognition of the nature of the texts, the goal of this research is not to extract or "liberate" women's voices from men's writings, but rather to explore how certain men, belonging to particular sectors of society, perceived women's experiences, vulnerabilities, and choices. Most of my sources are medical encyclopedias, religious advice books, and legal manuals.

From the medical texts, I have attempted to draw out information about the Arabo-Galenic gynecological heritage. Among the questions I ask are: what did physicians think it signified when a woman did not bear children? What did they think could have gone wrong? Were men blamed for infertility? Did gynecology serve as a field of discourse for reinforcing socially-approved gender roles? What sort of treatment options did physicians and pharmacists offer? How much contact did male medical practitioners have with female patients and female practitioners? Did male physicians expect that their writings on gynecological issues

29 Kueny, Conceiving Identities, 3. 
would ever be read, known, or applied by women themselves? The answers to these questions are described in chapters four and five of this book.

The bulk of this study is based on the writings produced by the fuqahā', Muslim jurists. The genres I make use of include theoretical law codes, fatwās (in which specific cases, whether theoretical or drawn from an individual life, are addressed by a jurist who clarifies the relevant points of law for the case at hand), books of advice and ethics based on Islamic sources (legal $a d a b$ ), hisba manuals (which instruct market inspectors how to go about ensuring public well-being), and anti-bid'a literature which decries "innovations" in social or religious life which are at odds with the author's views of Islamic orthodoxy.

The jurists' writings contain a treasure trove of information and yet are also full of shortcomings from the point of view of the social historian. The law was an institution which could potentially touch everyone, rich and poor, male and female, the educated and the uneducated - in a way which perhaps the AraboGalenic medical tradition did not. Even better, in their moralistic writings, the jurists reflect on the behaviors of people whom they feel they are unable to reach. Their writings thus, in theory, provide a window on to the lives of a broad swath of society. However, legal writings give us little information about those who were not in legal conflict and did not fear potential future conflict. When childless couples and their extended families took care of each other, they had no reason to have encounters with the legal system. Because this study utilizes legal material, it necessarily focuses on areas of conflict, the assertion or curbing of (usually male) power, and the transactional trading of familial privileges. That does not mean, of course, that in the communities described marriages and families necessarily lacked harmony or functioned on an entirely transactional basis.

Even more overtly inspirational moralistic literature, such as Ibn Muflih’s alAdāb al-shar ‘iyya, Ibn al-Jawzì’s Aḥkām al-nisā’, or Ibn al-Ḥājj’s Madkhal, which describes ideal behavior (while emphasizing the prevalence of misbehavior), tends to depict ideal marital life in terms of the assertion of a husband's responsibility and noblesse oblige, which is requited by his wife's surrender of power to him. This too should not be taken as indicative of typical family dynamics. Indeed, the authors themselves complain that both husbands and wives blithely ignore their advice on marital relationships. However, the unfortunate result is that this study does not and cannot address what are surely some of the most salient features of the experience of infertility: love, pity, and companionship.

A second significant shortcoming in the legal material I use is that, unlike court records, it is not locale and time specific. Legal manuals, and even fatwās and nawāzil, do not privilege the accurate depiction of local and contemporary practices. The scholars who produced the legal analyses and moralistic literature 
upon which much of my research is based were also not primarily concerned with producing an accurate account of the prevalent behavior or local customs found in their own communities. Rather they were more concerned with categorizing various behaviors as commendable or reprehensible and establishing an intellectual pedigree for those categorizations. When it comes to legal matters that affect infertile women, the legal scholars do depict diversity, but generally with respect to intellectual strands and schools of thought, rather than with respect to locality and period.

There are a few types of cases in which these authors do focus on changes over time or place. This occurs most prominently when there is a significant break between the views attributed to the Prophet Muhammad himself and the dominant position within a subsequent school of Islamic law. For example, on the issue of the desirability of women's prayer in mosques the Islamic authorities frequently acknowledge that while the Prophet permitted attendance, they themselves discourage it and justify that change on the grounds that contemporary women behave in a different (worse) fashion than the virtuous women of Medina. ${ }^{30}$ The opposite situation is also attested to, in which a previously disliked practice becomes widely permitted. For example, al-Sarakhsī (d. ca. 490 A.H./1096 A.D., in Transoxania) writes that in spite of 'A 'isha's condemnation of women who make use of bathhouses, "the correct position according to us is that there is no problem with having baths for either men or women because they have need of it, especially in our country." ${ }^{31}$ References to changes over time and place also appear frequently in anti-innovation treatises, in which the author distinguishes between "the pure law" and the degenerate practices which he attributes to his own local community. In this literature, the diversity of practice is depicted as a novel occurrence, a recent deviation from a previously univocal norm, rather than a product of deeply-rooted multivocal traditions. Confirming whether the so-called "degenerate" practices are common, rare, or entirely hypothetical is not always possible. ${ }^{32}$

This brings the reader back to the concerns about the fraught use of the adjectives "medieval" and "Islamic" societies. The problems with such terms are

30 M. H. Katz, Women in the Mosque: A History of Legal Thought and Social Practice (New York: Columbia University Press, 2014), 97.

31 Behnam Sadeghi, The Logic of Law-Making in Islam: Women and Prayer in the Legal Tradition (Cambridge: Cambridge University Press, 2013), 114.

32 E. g. In Ibn al-Hāijj al-'Abdarī's Madkhal written in the early 8th/14th century in Egypt, the author claims that Muslims women in Egypt, under the influence of their Christian and Jewish counterparts, have started observing "sabbaths” three days per week. Ibn al-Hāijj al-'Abdarī, Madkhal (Beirut: Dār al-Kutub al-'Ilmiyya, 1995), 1/2:201-2. 
manifest: they refer to communities separated by vast gaps in time and space, and which themselves draw on local traditions which may vary considerably, traditions that may have little relation to any one notion of "Islam." The texts I cite span from the $3^{\text {rd }} / 9^{\text {th }}$ centuries through the $8^{\text {th }} / 14^{\text {th }}$ centuries, and from Spain in the West, to Iraq in the East, and sometimes beyond. Can it be appropriate to write a sweeping overview of a topic through the use of sources from such diverse populations? The question becomes even more challenging because discourses on Islamic law and women are so often associated with attempts to depict the women of the Islamic world as universally "subjugated" and in need of "liberation" at the hands of the "modern West." In raising such concerns, Lila Abu-Lughod specifically cautions against writing in broad strokes.

Much of the best recent literature in Middle East women's history and anthropology can be conceived of as working against universalizing discourses about patriarchy, Islam, and oppression. Scholars have been seeking to specify, to particularize, and to ground in practice, place, class, and time the experiences of women and the dynamics of gender. ${ }^{33}$

It is doubtless worthwhile to examine how infertile women experienced Islamic law in specific communities; however, it would be a mistake to therefore conclude that our knowledge of history cannot benefit from engaging in "universalizing discourses." Broad discussions, such as those featured in Michael Dols's Majnūn: the Madman in Medieval Islamic Society, Avner Giladi's Children of Islam: Concepts of Childhood in Medieval Muslim Society and Basim Musallam's Sex and Society in Islam: Birth Control Before the Nineteenth Century lay out the contours of the intellectual landscape. They provide a framework which helps us to begin to answer what was important, what was axiomatic, what was conceivable, what was widespread, and what was controversial, even if they may potentially mislead us as to relative frequency of different modes of dealing with any particular issue. Indeed, it is only in the context of such a framework that we can hope to pinpoint and appreciate the extent to which local practices represent a deviation from, an alternative to, or a renegotiation of, the norms propounded by juristic writings. My choice to study "barren women in the medieval Islamic world" is therefore not intended to elide over or ignore the significant differences between and within populations, but rather to engage in the prerequisite work necessary for those differences to be recognized and appreciated.

33 L. Abu-Lughod, "Feminist Longings and Postcolonial Conditions," in Remaking Women, Feminism and Modernity in the Middle East, ed. L. Abu Lughod (Princeton: Princeton University Press, 1988), 22. 


\section{Parallels between communities separated by religion and time}

While the experiences of medieval Muslim women constitute the main topic of study, I also cite parallels and divergences between medieval Islamic Middle Eastern communities and medieval Christian European ones, as well as between Muslim and non-Muslim communities in the Middle East. My reasons for doing so are three-fold. First, there are some forms of historical data available from certain communities in medieval Christian Europe which are currently not available from any medieval Middle Eastern community. For example, scholars of European history have been able to start drawing conclusions about the age at which women in certain medieval communities reached various stages of physical maturity, based on data from exhumed skeletons. Secondly, because medieval Christian and Jewish communities in the Middle East shared both medical beliefs and economic conditions with their Muslim peers, but had different legal options when it came to infertility, at times it is easier to parse the concerns motivating non-Muslim women's legal strategies, and to thereby gain some sense of what mattered most to them. These are concerns which they may have shared with their Muslim neighbors, and they therefore shed light on what may have been women's concerns more broadly, regardless of religious boundaries.

Thirdly, it is worthwhile to note that many of those aspects of medieval women's experiences which modern egalitarian readers find most distasteful crossed confessional boundaries. In all three of the Abrahamic religions, women could be married off at very young ages. All three in some respect subordinated unmarried daughters to their fathers, and wives to their husbands. All three claimed that women's biological functions both determined and reflected their spiritual and social inferiority. This will come as no surprise to even the most casual student of medieval history and theology. However, it bears repetition given the contentious history of people denigrating Islam by drawing attention to the "plight" of Muslim women. It is my hope that if I can demonstrate the commonalities and peculiarities of the attitudes manifested by the different religious communities, honest assessments of women's comparative vulnerabilities and sources of power in those communities will not be viewed as a weapon to be wielded in contemporary ideological battles.

This study also makes extensive references to sources from other time periods, including from the modern Middle East. In particular, in the tradition of such historians of medieval social history as S. D. Goitein and Avner Giladi, I draw on modern ethnographies. ${ }^{34}$ Where I have located a legal or social strategy

34 E.g. S. D. Goitein, A Mediterranean Society: the Jewish Communities of the World as Portrayed 
that is employed by both modern women and medieval ones, I draw attention to how modern women characterize their thought process in employing that strategy. For example, women in medieval and early-modern Islamic societies sometimes made the choice to forfeit the inheritance which was their legal due, without providing an explanation for their doing so. Women living in twentiethcentury societies also sometimes make this choice, but we have interviews with those women in which they offer explanations of the social purpose and motivations behind their individual choices. These must necessarily be used with caution; they in no way offer proof of what motivated medieval women. But they can offer us perspectives and analysis that are worth our consideration. Similarly, I do not assume that the biological ideas espoused by rural Turkish women in Carol Delaney's The Seed and Soil or by urban lower-class Egyptian women in Inhorn's The Quest for Conception necessarily coincide with the beliefs of Anatolian or Egyptian women from centuries ago. It would be highly problematic to assume that ethnographic accounts from Morocco, Egypt, Iraq, and Iran depict age-old social practices in those respective regions, and I do not use them to project modern practices back in time. But modern women's experiences and perspectives are not less valuable and thought-provoking for being ungeneralizable.

\section{Sources excluded from this study which merit further inquiry: fictional literature, magic, and pilgrimage literature}

There are several genres is medieval literature which can perhaps provide us with insights into the topic at hand, but which have been excluded from this particular study. These include magical texts and artifacts, pilgrimage literature and histories describing festival observances, and popular literature. In a future book, I intend to examine these genres for evidence of women's fertility rituals. However, for the most part, I have excluded these genres from this work because of the methodological complications involved. Among these complications is the difficulty of evaluating the veracity of what are often vague or unsympathetic descriptions of women's fertility rituals, written by men who view such rituals with disdain. Should we reject the outraged depictions of women's rituals that come from medieval moralists, on the grounds that outrage indicates lack of credibility? Or should we accept them at face value or, somehow, stake out a middle

in the Documents of the Cairo Geniza (Los Angeles: University of California Press, 1978), 3:7. Giladi, Muslim Midwives, 137. 
ground? Even modern academic and sympathetic observers of fertility rituals are often quite shocked by them, yet it would be a mistake to dismiss their descriptions altogether. ${ }^{35}$ Determining the meaning of ritual performances is even more fraught, and it requires a greater degree of openness to speculation than the rest of this study does. Hence, it will be saved for a future one. The attractions and pitfalls of such speculation can be observed in Nicole Hansen's dissertation, "Motherhood in the Mother of the World: Continuity and Change of Reproductive Concepts and Practices in Egypt from Ancient to Modern Times."36

Other complications stem from the repetitions of tropes and the expectations of certain literary conventions, which in turn make it more difficult to explore fictional stories in search of clues to historical reality. However, certain celebrated stories may be useful in further illustrating concerns and phenomena regarding infertility which we also find in other genres. For example, the story of "Dalila the Crafty" in One Thousand and One Nights, depicts infertile characters using elements that will appear over and over again in the legal literature too. Consider Dalīla's victim Khātūn, the childless wife of a wealthy emir.

The chief of the caliph's officers ... was married to a beautiful girl whom he loved. On their wedding night she made him swear to take no other wife and to spend no single night away from home.

One day, when her husband went to the caliph's court, he noticed that each of the emirs was accompanied by one son or two, and then, when he went into the baths and looked at his face in the mirror, he saw that there were more white than black hairs in his beard. He said to himself: 'God took away your father and will He not provide you with a son?' He was in an angry mood when he went back to his wife, and when she wished him a good evening, he said: 'Get away from me. From the day that I first saw you nothing has gone right for me.' 'Why is this?' she asked, and he said: 'On our wedding night you made me swear to take no other wife. Today I saw that every single emir had one or two sons. I thought about dying without issue, and a man who leaves no heir will not be re-

35 A useful example of discomfort on the part of the anthropologist can be found in Inhorn's description of her observations of a fertility ritual at the tomb of Shaikh al-Khibari near Alexandria. Inhorn, Quest for Conception, 228-231. For an example of an unsympathetic medieval description of popular rituals, consider Ibn al-Ḥājj's claim that women hollow out bread, fill it with mouse dung, and eat it to facilitate easy childbirth. Ibn al-Ḥājj, al-Madkhal, 3/4:221.

36 Hansen, "Motherhood in the Mother of the World," 41. Throughout her work, Hansen notes the similarities between aspects of ancient and current fertility rituals in Egypt. She notes the similarity between circumambulation rituals, segregation of post-partum women, celebrations of week-old newborns, and the use of honey in medicines. However, without information as to what the women believe they are achieving through the use of these rituals it is virtually impossible to tell whether we are seeing an inherited continuity, a faux-continuity (in which rituals which originated in the modern period are backdated), or simply the convergence of practices which are common to many societies. 
membered, and I am angry because you are barren and cannot conceive by me.' His wife invoked God's Name against him and said; 'I have worn away mortars by pounding powders and medicines, and the fault is not mine but yours. You are a flat-nosed mule with watery and infertile sperm that cannot inseminate and produce children.' 'I am going on a journey,' he told her, 'and when I come back I shall take another wife.' 'It is God Who determines my fortune,' she told him. He then let and each of them was sorry or having blamed the other... .

Khatun [told Dalila] 'on my wedding night I made my husband swear that he would take no other wife. Then he looked at other men's son and, in his longing for them, he accused me of being barren, while I told him he was an infertile mule. He went off in a fit of anger, promising to take another wife when he came back from his journey. I am afraid that he will divorce me and marry another, as he is a man of property with a large income, and if he has sons by another wife it is they who will take the wealth and the property instead of me.' 'Daughter,' said Dalila, 'don't you know about my master, Abu'l-Hamalat? ${ }^{37}$ If any debtor goes to him as a pilgrim, God will free him of his debt, and any barren woman who visits him will conceive.' . . . Khatun told her that since the day of her wedding she had not left her house [not even] to offer condolences or congratulations. ${ }^{38}$

As shall be shown in the subsequent chapters, many elements of this story correlate with what we see in the medical and legal literature. As part of his marriage contract, the husband commits himself to monogamy, a very common stipulation in medieval Islamic marriage contracts. ${ }^{39}$ The pain of the emir's childlessness is deepened by the fact that he is also fatherless and stems from the sense that no one will remember him after his own death. At this point the husband blames the wife not only for being barren, but for closing off the possibility of a second marriage, and he seeks to renegotiate this part of the contract. This too is attested to elsewhere. The wife in turn blames her husband for their childlessness. The belief that infertility could stem from either husbands or wives is also well-attested to in medieval medical literature. The wife's concern that her husband's children by another wife would eventually appropriate her share of his estate is also reflected in the legal sources. And finally, the wife's remark that she has been constrained from seeking a treatment for her infertility at the hands of a holy man because she is so virtuous that she does not leave the

37 The name is a pun, referring to both pregnant women and debtors.

38 M. Lyons (translator), The Arabian Nights: Tales of 1,001 Nights Volume 2 (Penguin Classics: New York, 2010), 804.

39 K. Ali, "Marriage in Classical Islamic Jurisprudence: A Survey of Doctrines," in Frank Vogel and Asifa Quraishi, ed., The Islamic Marriage Contract (Cambridge: Harvard University Press, 2009) 23-25. A. Sonbol, "Shari“ Court Records And Fiqh As Sources Of Women’s History," Religion \& Literature, 42 (2010) 238. Goitein, Mediterranean Society, 3:149-50. 
house even for women's social activities, such as wedding celebrations and the paying of condolence calls, is also described in the jurists' writings.

\section{Chapters and structure}

Part I of this book explores the ways in which Islamic law could influence the experiences of infertile and childless women over the course of a lifetime, excluding the experience of medical intervention. The first chapter examines the significance of fertility as it is depicted in the early Islamic non-legal religious sources, particularly in the sira and the hadith, and explores the contrast between those texts and legal discussions of the role of fertility in marriage. The second chapter explores aspects of the reproductive life cycle that were the subject of a great deal of legal thought, including adolescent maturity, menarche, amenorrhea, and menopause. It shows how legal expectations of the reproductive cycle were in some ways at odds with the biological realities of many women. This, in turn, confused legal expectations about who was and was not likely to be infertile, pregnant, or potentially pregnant. The chapter further explores the prospects and the mechanisms of divorce and remarriage, and how reproductive dysfunctions complicated those procedures. Chapter 3 concludes this section with an exploration of the marital prospects of childless women and how childlessness affects the application of Islamic inheritance laws.

The second part of this book examines the perspectives we can gain on infertility from the Arabo-Galenic gynecological tradition. Chapter 4 describes the gynecological theory found in medieval medical texts and its relationship to the Greek medical tradition which it references. This choice of topic is based on the fact that the Arabic medical texts explored here explicitly claim Greek physicians as their primary authorities and, as will be shown in Part III, this had significance from the point of view of certain Islamic jurists. Chapter 5 discusses gender segregation, modesty concerns, medical interactions between the sexes, and the extent to which it was possible for gynecological ideas contained in medical books to have ever made a real impact on women's medical care. It aims to shed light on a question which has garnered attention from other scholars of the history of science and gender and society: whether specifically Islamic religious attitudes toward women's roles and towards gender-based separation are reflected in the Arabic medical writings about women's bodies.

The final part addresses attitudes toward medical treatment found in the writings of certain medieval jurists. Chapter 6 examines juristic depictions of the relationship between Arabo-Galenic medicine, the "medicine of the Prophet," and folk medicine. It argues that some jurists were concerned by the intel- 
lectual hybridity found in the medieval medical scene. They believed that people's desire for healing potentially led them to leverage supernatural forces other than God's, or to esteem as infallible truth pronouncements other than the Islamic revelation, or to put their trust in and offer their intimacy to nonMuslims. Chapter 7 argues that these same jurists were even more concerned about the potential for heterodoxy among women patients, particularly those seeking medical and ritual aid in dealing with significant moments in the life cycle and reproductive cycle. I argue that the jurists' stated preferences when it comes to who provides medical care to Muslim women demonstrate a concern with more than just modesty and the sexual dangers of female-male contact. Rather, they are motivated by a concern about intellectual influence, the dangers of female-female contact, and the rise of what they believe to be a gulf between Muslim women's culture, particularly as it relates to biology and the management of life cycle events, and the culture propagated by the jurists.

\section{Infertility as a locus for ambiguity, uncertainty, and compromise}

Among the most salient aspects of infertility is the way in which it foregrounds the uncertainty that people often lived with, on a biological, social, legal, and theological level. With regard to diagnosis, there was a pronounced resistance across the medieval Islamic world to legally or socially labeling either female infertility or male sterility as a permanent condition. One could not legally label one's spouse as infertile in the way one could, for example, label them as leprous. One could not be certain that a person who did not reproduce while they were young would also fail to reproduce while they were old. Indeed, as we shall see, even more obvious labels pertinent to reproduction, such as that of $y \bar{a}$ 'isa (the post-menopausal woman) were often not conferred upon women until very old age. The significance of diagnostic uncertainty is also readily apparent when we analyze how, in both the medical and legal realms, the symptoms of pregnancy and infertility were conflated. So too were the therapies intended to promote conception and those intended to promote abortion or contraception. This resulted in both legal and medical ambiguity and hence confusion, but that ambiguity also provided potentially vulnerable women with room to maneuver in their own perceived self-interest, both legally and medically.

There was also uncertainty about the marital consequences of infertility. In many Muslim communities, infertility could potentially precipitate polygamy, divorce, remarriage, social disconnection, or disinheritance, but it did not have to. 
These uncertainties also provided a broad range of opportunities for individuals to exercise choice, and to be influenced by the choices of their spouses and family members. This provided a flexibility which was not present to the same extent in societies dominated by Jewish or Christian views of marriage.

There was a tremendous amount of debate, ambivalence, and compromise surrounding healing itself, particularly for women. What constitutes effective medicine and what quackery? When does the pursuit of health constitute the reasonable exploitation of the cures set on earth by the beneficent God, and when does it suggest a lack of trust in that God? To whom should female patients turn for guidance? To male or female practitioners? To Muslims or non-Muslims? How much of a concern should avoiding physical immodesty be when seeking gynecological care? How much concern should there be to avoid heterodoxy, superstition, and dependency on those foreign to the household or to the religious community? The literature I have pieced together suggests that male physicians interacted with female patients and had few compunctions in doing so, yet there is also evidence that this interaction was viewed as suboptimal. Not only were interactions between male practitioners and female patients fraught, so also were interactions between female practitioners and their female patients, especially but not exclusively when the healers were non-Muslims.

Finally, this study highlights the multiple legal areas, pertaining specifically to women, in which there appears to be a significant tension between legal theory and social practice in many locales and time periods. These areas include: female socializing and ritual practices in gender-segregated settings, the role of women in transferring and preserving property between generations and families, the public demonstration of menstrual status, and the extent of interactions between men and women in medical settings. This tension is profoundly important when attempting to understand the ways in which Islamic law helped to shape the experiences of Muslim women, and when considering the malleability of religious discourse about gender and family roles. It has often been assumed that medieval Islamic law promoted a framework which placed intense pressure on women to have children and encouraged dissatisfaction with those who could not. Upon closer examination, however, we see that this pressure and dissatisfaction was not a one-way street. Islamic law did not condemn barren women, but rather had a disparately negative impact on them. Such disparate impact, combined with the fierce cultural desire for children, placed a strain on religious norms. It spurred individual women, their families, their medical practitioners, and their religious leaders to develop exceptions, reinterpretations, stratagems, and compromises in their negotiation of Islam. 
